\title{
A Variable Distributed Clark Unit Hydrograph Model for Urban Drainage System with Different Rainfall Intensity
}

\author{
Hongbin Shen ${ }^{1}$ and Zongxue $\mathrm{Xu}^{1}$ \\ ${ }^{1}$ Beijing Normal University
}

May 6, 2020

\begin{abstract}
Based on Clark unit hydrograph model, a variable distributed unit hydrograph model for urban drainage system is presented with different rainfall intensity. Firstly, urban watershed is decomposed into several individual sub-catchment units; then, different unit hydrograph for each sub-catchment unit is modeled as a single linear reservoir; finally different unit hydrograph is delayed and summed to outlet according the time of concentration along underground pipe network. The values of two model parameters including response parameter and delayed time of concentration can be directly estimated without the need of calibration considering the effect of rainfall intensity on flow velocity. The north region of Future Science Park in Beijing was selected as the study area, application results showed that: (1) the unit hydrograph for whole catchment area was different, in which the peak values increased with the increase of rainfall intensity, and the increasing rate showed gradual decrease tendency; (2) the simulated runoff processes are in reasonable agreement with the monitored runoff processes, in which the average value of R2 was 0.73 , which varied from 0.4 to 0.89 , the average value of NSE was 0.26 , which varied from -0.77 to 0.87 , the average value of $\mathrm{RE}$ was -0.18 , which varied from -0.77 to 0.36 ; (3) the unit hydrograph for each sub-catchment unit was spatially varying, and varied with the rainfall intensity, in which with the increase of rainfall intensity, the response parameter increased by the 0.4 power function and delayed time of concentration decreased by the -0.6 power function, respectively.
\end{abstract}

\section{Hosted file}

Main document.docx available at https://authorea.com/users/305283/articles/448553-a-variabledistributed-clark-unit-hydrograph-model-for-urban-drainage-system-with-differentrainfall-intensity

Hosted file

Table.docx available at https://authorea.com/users/305283/articles/448553-a-variabledistributed-clark-unit-hydrograph-model-for-urban-drainage-system-with-differentrainfall-intensity

\section{Hosted file}

Image file.docx available at https://authorea.com/users/305283/articles/448553-a-variabledistributed-clark-unit-hydrograph-model-for-urban-drainage-system-with-differentrainfall-intensity 